AL IBTIDA: JURNAL PENDIDIKAN GURU MI (2018) VOL 5 (2) : 221-230

DOI: http://dx.doi.org/ 10.24235/al.ibtida.snj.v5i2.3079

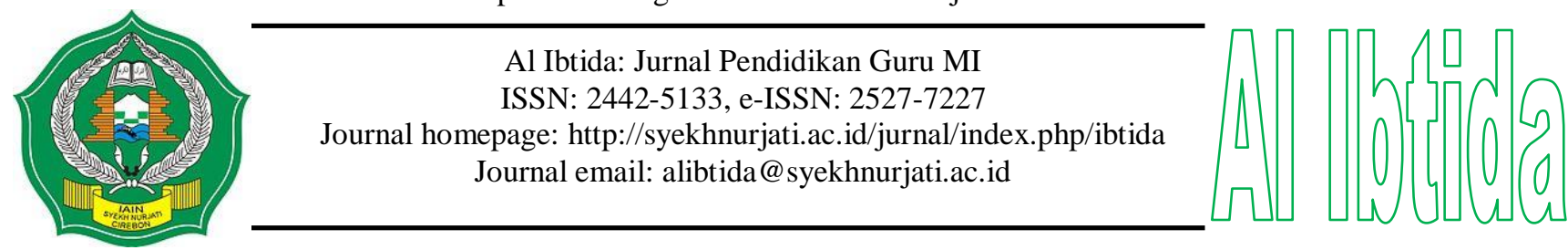

\title{
Peningkatan Kemampuan Mahasiswa PGSD Universitas Bung Hatta dalam Mengembangkan Bahan Ajar IPA Sekolah Dasar
}

\author{
Siska Angreni* \\ *Program Studi Pendidikan Guru Sekolah Dasar, Fakultas Keguruan dan Ilmu Pendidikan, \\ Universitas Bung Hatta Padang \\ Email: siskaangreni456@gmail.com
}

Received 27August 2018; Received in revised form: 08 October 2018; Accepted 12 October 2018.

Publish Online: 31 October 2018

\begin{abstract}
Abstrak
Penelitian ini bertujuan untuk mendeskripsikan kemampuan mahasiswa PGSD Universitas Bung Hatta dalam mengembangkan bahan ajar IPA di sekolah dasar. Jenis penelitian ini adalah penelitian kualitatif deskriptif dengan subjek penelitian adalah mahasiswa kelas D yang mengambil mata kuliah pengembangan bahan ajar semester genap tahun ajaran 2017/2018. Instrumen pengumpulan data berupa skor pada: (1) lembar penilaian silabus dan RPP, (2) lembar penilaian bahan ajar dan instrumen validasi bahan ajar. Data hasil penelitian kemudian dianalisis menggunakan analisis deskripif yang meliputi mereduksi data, penyajian data dan menarik kesimpulan. Hasil penelitian menunjukkan bahwa $79 \%$ mahasiswa sudah mampu menyusun silabus pembelajaran IPA dengan baik dan sangat baik, $81 \%$ mahasiswa sudah mampu menyusun RPP pembelajaran IPA dengan baik dan sangat baik, dan 41 mahasiswa sudah mampu mengembangkan bahan ajar dengan kategori layak digunakan dalam proses pembelajaran. Jadi dapat disimpulkan bahwa mahasiswa Program Studi Pendidikan Guru Sekolah Dasar Universitas Bung Hatta sudah mampu mengembangkan bahan ajar IPA sekolah dasar yang baik sesuai dengan langkah-langkah pengembangan bahan ajar.
\end{abstract}

Kata Kunci: pengembangan bahan ajar, ilmu pengetahuan alam, mahasiswa PGSD

\begin{abstract}
This research aims to describe the ability of student of the Elementary School Teacher Education Department at Bung Hatta University in developing science teaching materials for elementary school. The type of this research is descriptive qualitative with the research subject being class D students taking courses in the development of teaching materials for even semester 2017/2018 school year. Data collection instruments were in the form of scores on: (1) syllabus and lesson plan assessment sheets, (2) teaching material assessment sheet and teaching material validation instruments. The research data is then analyzed using descriptive analysis which includes reducing data, presenting data and drawing conclusions. The results showed that $79 \%$ of students had been able to compile a syllabus of science learning well and very well, $81 \%$ of students had been able to compile the lesson plan of science learning well and very well, and 41 students had
\end{abstract}


been able to develop teaching materials in the good category for use in the learning process. So it can be concluded that the students of Elementary School Teacher Education Department at Bung Hatta University have been able to develop science teaching materials in accordance with the steps of developing teaching materials.

Keywords: development of teaching materials, natural science, students of PGSD.

\section{PENDAHULUAN}

Salah satu kompetensi pedagogik guru sekolah dasar adalah mampu mengembangkan kurikulum/silabus (Permendiknas Nomor 16 Tahun 2017 tentang kualifikasi dan kompetensi guru). Dengan mengembangkan kurikulum/silabus maka guru terlatih untuk mengembangkan bahan ajar sesuai kemampuan dan karakteristik siswa sekolah dasar. Hal ini senada dengan Zulhandayani (2017) yang menyatakan bahwa kemampuan guru dalam mengembangkan kurikulum/silabus sesuai dengan kebutuhan peserta didik sangat penting, agar pembelajaran dapat berlangsung secara efektif dan menyenangkan. Sehingga dapat disimpulkan bahwa kegiatan dalam bahan ajar akan mempengaruhi apa yang disampaikan, cara dan langkah-langkah guru dalam mengajar (Nurmala, 2016). Dipertegas oleh Mudzanatun (2012) bahwa nuansa pembelajaran yang sesuai dengan karakteristik siswa dan dekat dengan dunia siswa dapat mendorong pemahaman secara utuh.

Bahan ajar memungkinkan siswa dapat mempelajari suatu kompetensi atau kompetensi dasar secara runtut dan sistematis sehingga secara akumulatif mampu menguasai semua kompetensi secara utuh dan terpadu (Kumala, 2016). Bahan ajar tidak hanya memuat materi tentang pengetahuan tetapi juga berisi tentang keterampilan dan sikap yang perlu dipelajari siswa untuk mencapai standar kompetensi yang telah ditentukan Pemerintah (Kumala, 2016). Oleh karena itu, mestinya guru terampil untuk mengembangkan bahan ajar yang berkualitas dalam rangka menunjang ketercapaian tujuan pembelajaran. Menurut (Valentina, 2015) bahwa bahan ajar dirancang untuk membantu guru dalam memberikan pengalaman belajar yang melibatkan proses mental dan fisik melalui interaksi antar peserta didik, peserta didik dengan guru, lingkungan, dan sumber belajar lainnya dalam rangka pencapaian kompetensi dasar.

Pentingnya pengembangan bahan ajar oleh guru didasari bahwa banyaknya pokok bahasan yang memerlukan pemahaman yang kadangkala tidak ditemukan di buku teks, antara lain pada mata pelajaran IPA. Mata pelajaran Ilmu Pengetahuan Alam (IPA) menekankan pemahaman konsep yang berkaitan dengan kehidupan sehari-hari. Untuk mewujudkan pembelajaran yang bermakna maka materi pembelajaran mestinya dikemas dalam bentuk yang menarik dan dekat dengan kehidupan sehari-hari. Sesuai pernyataan Widiasih (2007) guru perlu menciptakan suasana belajar yang dapat menumbuhkan rasa percaya diri anak. Salah satunya dengan menciptakan bahan ajar IPA sesuai karakteristik pelajaran IPA dan perkembangan siswa 
sekolah dasar. Pengembangan bahan ajar IPA yang sesuai dengan karakteristik dan perkembangan siswa diyakini dapat meningkatkan motivasi dan hasil belajar siswa. Dipertegas oleh (Purnomo, 2017) bahwa masih banyak keterbatasan pada bahan ajar IPA yang tersedia sekarang ini. Menurut Valentina (2015) pengembangan bahan ajar dapat memberikan kemudahan bagi siswa dalam menguasai keterampilan yang telah ditentukan dalam sebuah proses pembelajaran. Keberhasilan penyelenggaraan pendidikan dapat dipengaruhi oleh beberapa faktor salah satunya adalah kesiapan guru dalam mempersiapkan peserta didik melalui proses pembelajaran (Sari \& Angreni, 2018)

Kenyataan yang ada, pengembangan bahan ajar yang seharusnya dilakukan oleh guru belum maksimal. Pada umumnya guru lebih cendrung menggunakan buku cetak dari penerbit tanpa merevisi sesuai dengan standar isi yang ada dalam kurikulum. Hal ini disebabkan belum timbul kesadaran bahwa penting untuk mengembangkan bahan ajar serta pengaruhnya terhadap prestasi siswa. Menurut Widiyatmoko (2012) kriteria pembelajaran IPA yang baik sesuai Kurikulum Tingkat Satuan Pendidikan tidak cukup hanya bersumber pada buku saja, tapi pengajaran itu harus dilengkapi alat praktek serta dihubungkan dengan lingkungan sekitar.

Oleh karena itu, kemampuan mengembangkan bahan ajar perlu dilatih sejak bangku perguruan tinggi, agar memiliki kemampuan yang mumpuni saat menjadi guru. Jalal (2009) mengatakan bahwa pendidikan yang bermutu sangat bergantung pada keberadaan pendidik yang bermutu. Peran pembelajaran pada perguruan tinggi dalam mendidik Sumber Daya Manusia mahasiswa sebagai calon guru menjadi hal yang sangat penting. Agar pembelajaran yang dilaksanakan tidak dominan menekankan aspek kognitif semata dan kurang melibatkan mahasiswa maka dilakukan terobosan baru yaitu meningkatkan hasil belajar psikomotor dalam hal ini menghasilkan produk yang bermanfaat bagi mereka nantinya.

Proses pembelajaran matakuliah pengembangan bahan ajar di program studi pendidikan guru sekolah dasar (PGSD) Universitas Bung Hatta bertujuan untuk membekali mahasiswa agar memiliki pengetahuan tentang cara mengembangkan bahan ajar yang bermanfaat dalam proses pembelajaran IPA di SD. Sesuai dengan Permenpan No 16 tahun 2009 tentang jabatan fungsional guru dan angka kredit, pada Bab V pasal 11 menyebutkan bahwa pengembangan profesi guru dapat dilakukan melalui pengembangan karya inovatif yang meliputi: 1) karya tulis ilmiah, 2) menemukan teknologi tepat guna termasuk membuat/memodifikasi alat peraga/praktikum, 3) menemukan/menciptakan karya seni, dan 4) mengikuti pengembangan penyusunan standar, pedoman, soal dan sejenisnya. Dari keempat kategori karya inovatif tersebut, satu diantaranya dikaji secara lebih mendalam dalam mata kuliah tersebut karena sesuai dengan kebutuhan guru IPA yaitu mengembangkan dan membuat bahan ajar IPA. Oleh karena itu, dalam proses pembelajaran mahasiswa perlu diberi kesempatan berlatih menghasilkan produk yaitu bahan ajar 
IPA. Sulestry (2018) menyatakan bahwa pengalaman belajar kepada siswa diawali dengan sesuatu yang real bagi mareka. Matakuliah pengembangan bahan ajar yang berbobot sks 3 tersebut merupakan matakuliah pokok yang ditawarkan pada mahasiswa semester 6. Matakuliah pengembangan bahan ajar sebagai uji kompetensi mahasiswa dalam menguasai silabus serta menghasilkan bahan ajar untuk mata pelajaran Ilmu Pengetahuan Alam (IPA) di sekolah dasar. Tujuan penelitian ini adalah melakukan kajian dalam rangka memperoleh deskripsi kemampuan mahasiswa dalam mengembangkan bahan ajar, mendeskripsikan langkah pengembangannya, kemudian mengembangkan bahan ajar.

\section{METODE PENELITIAN}

Penelitian ini menggunakan pendekatan kualitatif deskriptif dengan tujuan mendeskripsikan kemampuan mahasiswa program studi PGSD dalam mengembangkan bahan ajar IPA yang menarik dan layak digunakan dalam proses pembelajaran di sekolah dasar. Subjek penelitian ini adalah mahasiswa program studi pendidikan sekolah dasar yang mengambil mata kuliah pengembangan bahan ajar yang berjumlah 43 mahasiswa. Instrumen utama dalam penelitian ini adalah peneliti. Penelitian ini terdiri dari 3 tahap yaitu tahap persiapan, tahap pelaksanaan dan tahap penyelesaian.

Tahap pertama dimulai dari persiapan, diantaranya (1) menyiapkan lembar penilaian silabus dan RPP (2), menyiapkan lembar penilaian dan validasi bahan ajar (3) menentukan dosen validator bahan ajar. Proses pengembangan bahan ajar disesuaikan dengan tahapan R \& D (Sugiyono, 2011). Kriteria penilaian untuk bahan ajar menggunakan kriteria BNSP dimodifikasi oleh Angreni (2017). Setelah instrumen tersusun, selanjutnya lembar instrumen tersebut divalidasi oleh pakar. Instrumen menggunakan skala likert. Tahap kedua adalah kegiatan pelaksanaan. Kegiatan yang dilakukan pada tahap ini adalah mengumpulkan data berdasarkan instrument yang telah disiapkan kemudian mengolah data tersebut. Tahap ini dilakukan selama perkuliahan berlangsung, yang terdiri dari 16 kali pertemuan. Tahap ketiga adalah penyelesaian meliputi penganalisisan data yang diperoleh, menyajikan data dan menyusun laporan.

Sumber data sepenuhnya berupa data primer, karena diperoleh langsung dari mahasiswa dan peneliti. Data berupa skor yang diperoleh dari instrumen lembar penilaian silabus dan RPP, lembar penilaian dan validasi bahan ajar.Teknik analisis data diperoleh dari data kuantitatif yang didapatkan dari lembar penilaian silabus dan RPP, lembar penilaian dan validasi bahan ajar. Teknik analisis data yang digunakan dalam penelitian ini mengikuti konsep yang diberikan Miles dan Huberman 1992 dalam (Manurung, 2017) yaitu mereduksi data, penyajian data dan menarik kesimpulan. 


\section{HASIL DAN PEMBAHASAN}

Berdasarkan hasil analisis instrumen penelitian diperoleh data (1) penilaian silabus dan Rencana Pelaksanaan Pembelajaran, (2) hasil lembar validasi yang diperoleh dari validator bahan ajar.

\section{Hasil Analisis Penilaian Silabus}

Berdasarkan hasil analisis instrumen penilaian diperoleh data bahwa terdapat tujuh aspek penilaian pada silabus yaitu (1) kompetensi dasar, (2) materi pokok, (3) kegiatan pembelajaran, (4) indikator, (5) penilaian, (6) alokasi waktu, (7) sumber belajar. Sebelum penilaian dilakukan, mahasiswa menentukan terlebih dahulu standar kompetensi dan kompetensi dasar yang akan dikembangkan menjadi bahan ajar. Standar kompetensi dan kompetensi dasar yang dikembangkan adalah kelas 4, 5 dan 6. Silabus disusun berdasarkan standar kompetensi dan kompetensi dasar yang dipilih. Adapun materi yang dikembangkan berasal dari standar kompetensi berikut:

Tabel 1. Standar Kompetensi yang dikembangkan

\begin{tabular}{llc}
\hline No & \multicolumn{1}{c}{ Standar Kompetensi } & Kelas \\
\hline Memahami hubungan antara struktur organ tubuh manusia dengan & \\
fungsinya, serta pemeliharaannya & \\
Memahami hubungan antara struktur bagian tumbuhan dengan fungsinya & \\
Menggolongkan hewan, berdasarkan jenis makanannya & Kelas IV \\
Memahami daur hidup beragam jenis makhluk hidup & \\
1 Memahami hubungan sesama makhluk hidup dan antara makhluk hidup & \\
dengan lingkungannya & \\
Memahami beragam sifat dan perubahan wujud benda serta berbagai cara & \\
penggunaan benda berdasarkan sifatnya & \\
\hline Mengidentifikasi fungsiorgan tubuh manusia dan hewan & \\
Memahami cara tumbuhanhijau membuat makanan & \\
Mengidentifikasi cara makhluk hidup menyesuaikan diri dengan & \\
lingkungan & \\
Memahami hubungan antara sifat bahan dengan penyusunnya dan & \\
perubahan sifat benda sebagai hasil suatu proses & \\
Memahami hubungan antara gaya, gerak, dan energi, serta fungsinya & \\
\hline Memahami hubungan antara ciri-ciri makhluk hidup dengan lingkungan & \\
tempat & \\
Memahami cara perkembangbiakan makhluk hidup & \\
Memahami pengaruh kegiatan manusia terhadap keseimbangan lingkungan & \\
Memahami pentingnya pelestarian jenis makhluk hidup untuk mencegah Kelas VI \\
kepunahan
\end{tabular}


Adapun data hasil penilaian silabus dapat disajikan sebagaimana diagram 1 berikut:

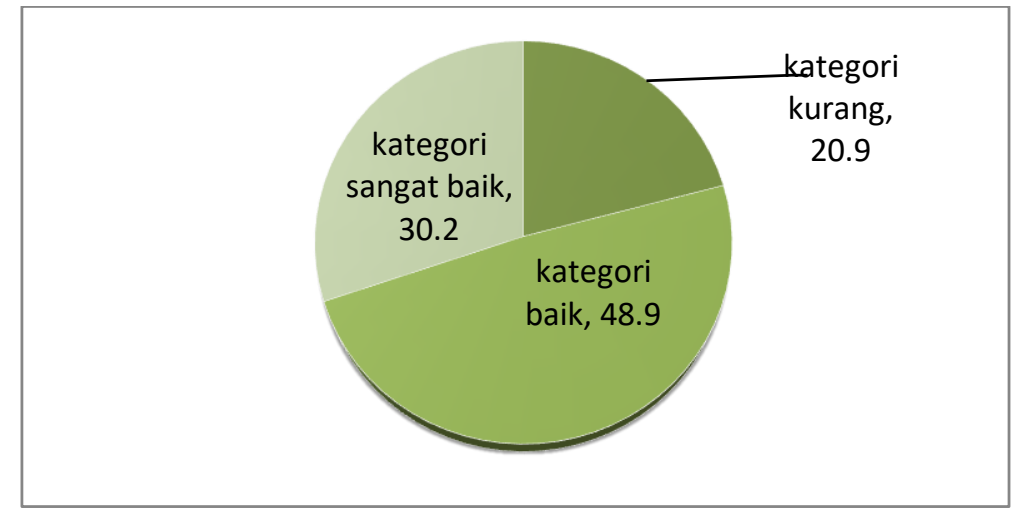

Digram 1. Persentase skor penulisan silabus

Berdasarkan diagram 1 menunjukkan bahwa dari 43 mahasiswa, 20,9\% mahasiswa memperoleh kategori kurang, 48,9\% memperoleh kategori baik dan 30,2\% mahasiswa kategori sangat baik. Dari 20,9\% kategori kurang tersebut, penyebabnya adalah 23,3\% pada aspek penilaian tidak lengkap ditulis jenis penilaian yang akan dilakukan. Misalnya jenis penilaian tertulis, tetapi tidak dicantumkan essay, objektif atau isian dan lain-lain. Sejumlah $30,2 \%$ tidak sesuai alokasi waktu dengan indikator yang direncanakan. Sebagai contoh untuk satu kompetensi dasar dikembangkan sehingga diperoleh 12 indikator. Untuk menentukan jumlah pertemuan dari 12 indikator maka harus disesuaikan dengan jam pelajaran IPA di sekolah dasar kelas 4, 5 atau 6. Dalam hal ini banyak mahasiswa yang belum memahami, sehingga dijelaskan lebih lanjut. Kemudian 46,5\% lainnya sudah menyusun silabus dengan baik. Berdasarkan hasil analisis dari penilaian silabus diperoleh data bahwa penyusunan silabus secara umum sudah dibuat dengan baik

\section{Hasil Analisis Penilaian Rencana Pelaksanaan Pembelajaran (RPP)}

Berdasarkan hasil analisis instrumen diperoleh data bahwa ada 10 aspek penilaian pada Rencana pelaksanaan pembelajaran (RPP), yaitu mencantumkan: (1) identitas RPP, (2) standar kompetensi, (3) kompetensi dasar, (4) tujuan pembelajaran, (5) metode/model/ strategi pembelaajran yang digunakan, (6) kegiatan pembelajaran, meliputi kegiatan pendahuluan, kegiatan inti dan kegiatan penutup (7) sumber belajar, (8) jenis evaluasi yang akan digunakan, (9) melampirkan sarana/alat peraga sesuai materi, (10) melampirkan kelengakapan sesuai dengan model/metode/strategi/pendekatan pelajaran yang digunakan.

Hasil analisis dari penilaian RPP diperoleh data bahwa secara umum mahasiswa sudah terlatih menyusun rencana pelaksanaan pembelajaran. Berdasarkan analisis data dari 43 mahasiswa 34,9\% kategori sangat baik, 46,5\% mahasiswa kategori baik dan 18,6\% mahasiswa kategori kurang. Berdasarkan data yang diperoleh terlihat bahwa penyusunan RPP yang dibuat oleh mahasiswa sudah baik. Hal ini karena penyusunan Rencana Pelaksanaan pembelajaran sudah dipelajari pada matakuliah pembelajaran IPA semester 4. Secara 
substansi mereka sudah memahami komponen-komponen RPP dan cara menulis RPP dengan baik. Meskipun demikian ada beberapa mahasiswa yang masih belum terampil menyusun RPP dengan baik. Terutama pada komponen kegiatan pembelajaran, mereka sulit untuk membedakan kegiatan inti subbagian eksplorasi, elaborasi dan konfirmasi. Adapun hasil penilaian RPP dapat disajikan pada diagaram 2 berikut.

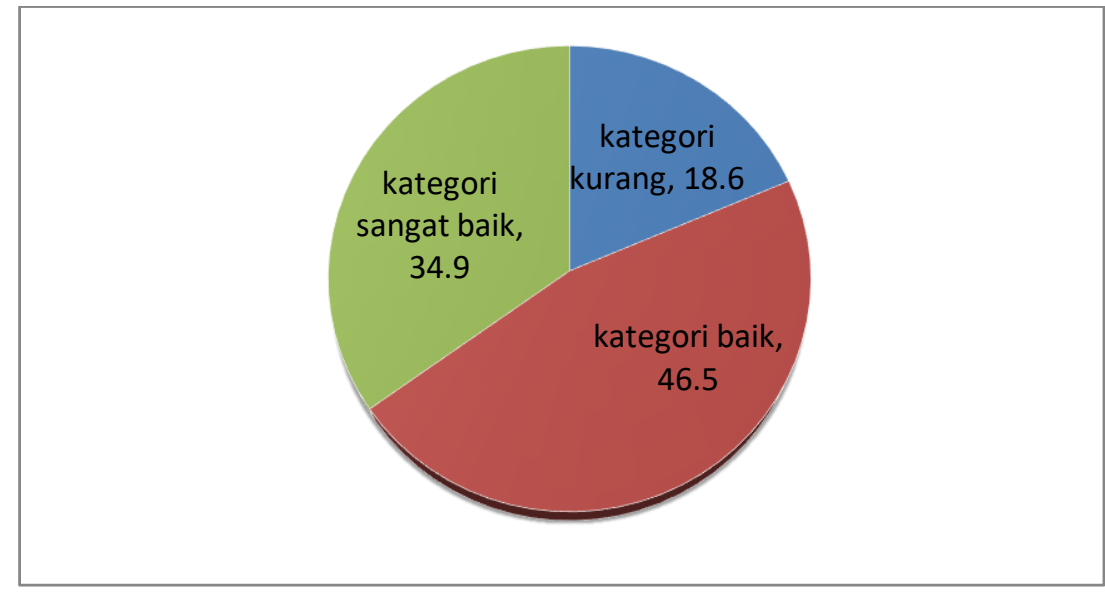

Diagram 2. Persentase skor penilaian RPP

\section{Analisis Hasil Validasi Pakar}

Berdasarkan hasil validasi pakar diperoleh data bahwa pengembangan bahan ajar IPA sekolah dasar yang dikembangkan oleh mahasiswa PGSD Universitas Bung Hatta mendapat kategori layak/valid. Penilaian bahan ajar IPA yang dikembangkan oleh mahasiswa meliputi 2 tahap yaitu: (1) kesesuaian komponen bahan ajar yang terdiri dari judul/identitas bahan ajar, petunjuk belajar, SK-KD dan indikator, materi pembelajaran, informasi pendukung, paparan isi materi, latihan, penilaian; (2) penilaian bahan ajar oleh validator menggunakan lembar validasi. Proses validasi bahan ajar sesuai saran perbaikan dari validator. Proses pengembangan bahan ajar disesuaikan dengan tahapan R \& D (Sugiyono, 2011).

Berdasarkan analisis data dari hasil penilaian bahan ajar yang meliputi komponen bahan ajar, secara umum memenuhi kriteria bahan ajar. Hasil analisis diperoleh bahwa 34,9\% mahasiswa termasuk kategori kurang, 44,2\% mahasiswa termasuk kategori baik, dan 20,9\% mahasiswa termasuk kategori sangat baik. Berdasarkan hasil persentase yang diperoleh penyebabnya sangat beragam, diantaranya tidak menuliskan informasi pendukung. Selain itu ada juga yang tidak menuliskan petunjuk belajar dan tidak melampirkan alat evaluasi. Proses penilaian bahan ajar dilakukan selama penyusunan draf bahan ajar IPA. Pada bagian ini juga ditentukan pendekatan pembelajaran yang cocok dengan isi materi. Setelah melakukan tahap penyusunan draf bahan ajar serta melakukan penilaian langkah selanjutnya menyusun lembar validasi bahan ajar. Kemudian menentukan validator untuk memvalidasi bahan ajar yang sudah dibuat. Penentuan validator dilakukan oleh mahasiswa dan peneliti dengan persyaratan validator harus sesuai dengan bidang keahliannya. Satu bahan ajar divalidasi oleh satu orang 
pakar. Proses memvalidasi bahan ajar termasuk perbaikan hanya dilakukan $3 \mathrm{kali}$, mengingat batas jumlah pertemuan perkuliahan. Pengetahuan mahasiswa terhadap materi sangat menentukan kualitas bahan ajar yang dikembangkannya.

Berdasarkan hasil validasi oleh validator diperoleh data yaitu dari 43 mahasiswa yang mengembangkan bahan ajar IPA dengan perolehan nilai sebagai barikut: 2 mahasiswa memperoleh nilai rerata 1 dengan kategori bahan ajar tidak valid/tidak layak, 26 mahasiswa memperoleh nilai rerata kurang dan sama dengan 2,75 dengan kategori layak dengan revisi, 15 mahasiswa memperoleh nilai rerata lebih besar dari 2,75 dengan kategori layak tanpa revisi. Berdasarkan perolehan nilai setelah dilakukan validasi terlihat ada 2 bahan ajar mahasiswa yang tidak layak/tidak valid hal ini dikarenakan pada proses perkuliahan masih ada mahasiswa yang tidak paham tentang apa yang dikerjakan. Tidak ada kesesuaian antara materi dengan pendekatan pembelajaran yang di gunakan dalam pengembangan bahan ajar. Selain itu keseriusan juga menjadi factor penentu kualitas bahan ajar yang dikembangkan. Selanjutnya ada 26 bahan ajar mahasiswa yang layak dengan revisi. Hal ini dikarena proses validasi dan waktu memperbaiki bahan ajar sesuai saran validator yang relative singkat. Sehingga menyebabkan bahan ajar yang dikembangkan harus mengalami perbaikan lagi. Pada umumnya perbaikan terakhir lebih banyak mengacu kepada tampilan karena ada beberapa tampilan bahan ajar yang tidak sesuai dengan karakteristik siswa sekolah dasar dan kontras warna yang menyolok.

Meskipun hampir $60 \%$ mahasiswa memperoleh nilai 2,75 yaitu layak dengan revisi namun mahasiswa sangat antusias dalam mengikuti proses perkuliahan. Pengalaman mengembangkan bahan ajar merupakan pengalaman yang sungguh menyenangkan. Mahasiswa mendapat pengalaman dan belajar aktif dalam mengerjakan bahan ajar (Widyaningrum, 2016). Dengan pengalaman ini mahasiswa memiliki kemampuan dalam mengembangkan bahan ajar untuk diaplikasikan nantinya. Karena tugas seorang guru bukan saja mengajar dalam kelas. Untuk meningkatkan profesionalisme guru, guru harus bisa mengembangkan materi yang diajarkannya. Menurut Zuriah (2016) salah satu kompetensi guru adalah mengembangkan materi pembelajaran yang diampu secara kreatif. Guru tidak hanya mengandalkan buku paket yang tersedia. Hal inilah yang menjadi alasan penelitian ini dilakukan. Mahasiswa PGSD merupakan calon guru yang akan mengajar di sekolah dasar, maka dari itu calon guru harus memiliki ilmu yang memadai untuk diaplikasikan ke sekolah. Paling tidak ada tiga tanggung jawab (kewajiban) yang dipercayakan pada guru-guru, mulai dari mengembangkan silabus, mengadakan materi ajar, dan melaksanakan penilaian hasil belajar yang kompleks dan berbeda (Mirizon, 2008). Dipertegas oleh Yenni (2016) guru dan 
calon guru harus terampil mengemas rencana pembelajaran yang efektif, menyenangkan dan sesuai dengan waktu yang sudah ditentukan.

Selanjutnya bahan ajar yang dihasilkan dapat digunakan secara berkelanjutan baik oleh mahasiswa maupun guru sekolah dasar. Bahan ajar cetak baik berupa Modul, handout, buku atau LKS pemanfaatannya dapat berkelanjutan tidak sebatas penelitian bahkan hingga pergantian tahun dan kurikulum bahan ajar cetak masih bisa terus digunakan, penggunaanya mudah dan praktis, tidak memerlukan fasilitas dan keahlian khusus dari sekolah hingga bisa digunakan siapa saja (Octaviani, 2017). Selain itu, kegiatan pengembangan bahan ajar yang dilakukan selama perkuliahan menumbuhkan karakter mahasiswa, yaitu disiplin, tanggung jawab, rasa ingin tahu, kreatif, inovatif, dan mandiri. Hal ini senada dengan hasil penelitiannya (Kumala, 2016) yang mengungkapkan bahwa penyajian bahan ajar yang mengembangkan pembelajaran berbasis karakter memunculkan karakter-karakter yang positif terhadap mahasiswa.

\section{SIMPULAN}

Berdasarkan hasil penelitian yang telah diuraikan, maka dapat disimpulkan sebagai berikut:

1. Mahasiswa PGSD FKIP Universitas Bung Hatta sudah mampu menyusun silabus pembelajaran IPA dengan baik. Hal ini dapat dilihat dari hasil analisis data bahwa 79,\% mahasiswa termasuk pada kategori baik dan sangat baik.

2. Mahasiswa PGSD FKIP Universitas Bung Hatta sudah mampu menyusun rencana pelaksanaan pembelajaran (RPP) pembelajaran IPA dengan baik. Hal ini dapat dilihat dari hasil analisis data bahwa $81 \%$ mahasiswa termasuk pada kategori baik dan sangat baik.

3. Mahasiswa PGSD FKIP Universitas Bung Hatta sudah mampu mengembangkan bahan ajar pembelajaran IPA dengan baik dan layak digunakan. Hal ini dapat dilihat dari hasil analisis data bahwa 41 mahasiswa atau 95\% mahasiswa sudah mampu mengembangkan bahan ajar dengan kategori layak tanpa revisi dan layak dengan revisi. 


\section{DAFTAR PUSTAKA}

Angreini, S., \& Azkiya, H. (2018). Development of Practical Instructions For Media Integrated Instruments Components Science Natural Science Elementary School Approach Skin Process Approach. International Journal of Recent Scientific Research, 9(7), 2820928213.

Jalal, F. (2009). Teacher certification in Indonesia. Departemen Pendidikan Indonesia.

Kumala, F. N. \& Hartatik. (2016). Pengembangan Bahan Ajar Kuliah IPA Berbasis Karakter. Jurnal Pancaran, 5(3), 81-98.

Manurung \& Mayor, M. H. (2017). Analisis Kemampuan Mahasiswa dalam Menyelesaikan Tugas Pengajuan Soal Integral ditinjau dari Perbedaan Kemampuan Matematika. Jurnal Ilmiah Matematika dan Pembelajarannya, 1(1), 38-42.

Mirizon, S. \& Yunus. (2008). Some Aspects of English Competency Based Curriculum. Jurnal Forum Kependidikan, 24(1), 67-86.

Mudzanatun, Wiyanto, A., \& Fajriyah, K. (2012). Peningkatan Kemampuan Pengembangan Bahan Ajar Tematik SD Pada Mahasiswa S1 PGSD IKIP PGRI Semarang. Jurnal Media Penelitian Pendidikan, 6(1),1-8.

Octaviani, S. (2017). Pengembangan Bahan Ajar Tematik Dalam Implementasi Kurikulum 2013 Kelas 1 Sekolah Dasar. Jurnal Eduhumaniora, 9(2), 93-98.

Purnomo, H. \& Arrofa, A. (2017). Pengembangan Bahan Ajar dan Penilaian Otentik Mata Kuliah Pendidikan IPA Sekolah Dasar. Jurnal Profesi Pendidikan Dasar. 4(2), 167-179.

Sari, R. T., \& Angreni, S. (2018). Penerapan Model Pembelajaran Project Based Learning (PjBL) Upaya Peningkatan Kreativitas Mahasiswa. Jurnal Varidika, 30(1), 79-83.

Sugiyono. (2011). Metode Penelitian Kuantitatif, Kualitatif, dan R\&D. Bandung: Alfabeta

Sulestry, A. I. (2018). Analisis Kemampuan Menyelesaikan Soal Cerita Matematika Pada Siswa Kelas VII Smp Negeri 1 Bulukumba. Prosiding Seminar Nasional, 3(1).

Valentina, A., Riswandi, R., \& Rohani, C. (2015). Pengembangan Bahan Ajar Di Kelas V Sd Negeri 2 Labuhan Ratu. Jurnal Pedagogi, 3(5), 5-14.

Widiasih. (2007). Penggunaan Peralatan dari Lingkungan Sekitar Untuk Pembelajaran IPA di Sekolah Dasar. Jurnal Pendidikan, 8(2), 92-100.

Widiyatmoko, A., \& Pamelasari, S. D. (2012). Pembelajaran Berbasis Proyek Untuk Mengembangkan Alat Peraga IPA dengan Memanfaatkan Bahan Bekas Pakai. Jurnal Pendidikan IPA Indonesia, 1(1), 51-56.

Widyaningrum, \& Diyah, A. (2016). Penerapan Model Pembelajaran Berbasis Proyek Untuk Meningkatkan Aktivitas Belajar Mahasiswa pada Matakuliah Pengembangan Bahan Ajar. Jurnal Saintifika. 18(1), 1-7

Yenni, Y. (2017). Analisis Kemampuan Mahasiswa Dalam Menyiapkan Pembelajaran Yang Efektif Pada Mata Kuliah SBMM. Jurnal Penelitian dan Pembelajaran Matematika, 10(2), 133-145

Zulhandayani, Mahmud, H.R., \& Bukhari. (2017). Deskripsi Kompetensi Pedagogik Guru di SD Negeri 40 Banda Aceh. Jurnal Ilmiah Pendidikan Guru Sekolah Dasar. 2(1), 193-203.

Zuriah, N., Sunaryo, H., \& Yusuf, N. (2016). Ibm Guru Dalam Pengembangan Bahan Ajar Kreatif Inovatif Berbasis Potensi Lokal. Jurnal Dedikasi, 13(1), 9-49. 